\title{
Ketercapaian Perwujudan Lingkungan Permukiman Layak Huni Dalam Rangka Program Penataan Lingkungan Permukiman Berbasis KOMUNitAS (PLPBK) Di KABUPATEN KARANGANYAR
}

\author{
Diana Putri Wijayanti, Murtanti Jani Rahayu, Rizon Pamardhi Utomo \\ Prgram Studi Perencanaan Wlayah Dan Kota \\ Jurusan Arsitektur Fakultas Teknik \\ Universtas Sebelas Maret Surakarta \\ email: putriwijayantidiana@yahoo.co.id
}

\begin{abstract}
: poverty and slums are two things that can not be separated and a problem that often occurs in a region. Just as Karanganyar which has a fairly high level of poverty, it also illustrates the low quality of life. therefore implemented PLPBK program as a form of government intervention in housing issues. However, in practice there are problems that the program is considered less able to resolve the housing problem. This study was conducted to determine how the program realizes a good settlement in the framework of the program PLPBK in Karanganyar. This study not only look at the extent to which an increase in physical conditions that occur after the implementation of the program, but also how the level of the physical condition of the environmental suitability criteria habitable settlements are seen on the circumstances of each physical element neighborhoods include commercial facilities, educational facilities, health facilities, public service facilities, open space facilities, roads, drainage, sewage, garbage and water. The conclusion by looking at the physical condition of the environment in the study area is known that the physical condition of the environment has increased high at $74.3 \%$, while for the level of suitability of the physical condition of settlements with settlement criteria livable rated high at $87.2 \%$. So that the known increase in the level of suitability and physical condition of neighborhoods, achievement embodiment livable neighborhoods in order PLPBK program in Karanganyar assessed achieved
\end{abstract}

Keyword : livable, settlements, PLPBK

\section{PENDUHULUAN}

Kondisi permukiman berbanding lurus dengan tingkat kesejahteraan masyarakat. Semakin rendah kesejahteraan penduduk maka semakin rendah pula kondisi permukiman yang mereka diami (Maslow dalam Hariyono. 2007). Rendahnya kualitas permukiman dikarenakan masyarakat miskin tidak mampu memenuhi hak-hak dasarnya dalam memenuhi kebutuhan hidup serta kurangnya kemampuan masyarakat miskin dalam memelihara serta memperbaiki kualitas lingkungan hidup yang mereka diami. Hal ini mengakibatkan munculnya permasalahan perumahan dan permukiman.
Perkembangan perumahan dan permukiman di Indonesia tidak terlepas dari adanya permasalahan kemiskinan dan permukiman tidak layak huni, seperti halnya di Kabupaten Karanganyar pada tahun 2009 terdapat 87.290 rumah tangga (RT) yang terbagi dalam empat kategori miskin. Jumlah tersebut terdiri atas $8,17 \%$ RT sangat miskin, $12,33 \%$ RT miskin, 29,8\% RT hampir miskin, dan 49,6\% RT rentan miskin (Karanganyar Dalam Angka, 2010). Angka kemiskinan di Kabupaten Karanganyar terbilang cukup tinggi, hal ini menggambarkan rendahnya kualitas hidup masyarakat yang juga mempengaruhi kualitas lingkungan permukiman masyarakat miskin di 
Kabupaten Karanganyar. Oleh karena itu pada tahun 2009, pemerintah Kabupaten Karanganyar melaksanakan strategi penataan lingkungan permukiman kumuh melalui program PLPBK yang juga merupakan program nasional penanggulangan kemiskinan melalui penataan lingkungan permukiman tidak layak huni.

Namun dalam pelaksanaan program PLPBK di Kabupaten Karanganyar tidak terlepas dari berbagai permasalahan, antara lain program yang dilaksanakan dirasa kurang mampu menyelesaikan masalah permukiman secara menyeluruh, hal ini dikarenakan penjaringan aspirasi masyarakat melalui rembug warga dan pemetaan swadaya tidak mendapatkan hasil yang optimal. Ditambah lagi, karena kemitraan (channeling) yang di lakukan oleh BKM tidak berjalan dengan baik mengakibatkan dana yang dibutuhkan tidak sesuai dengan target, sehingga banyaknya rencana pembangunan yang tidak terlaksana (Wawancara Instansi, 2014).

Menurut PERMENPERA (2008), pemukiman layak huni adalah lingkungan hidup di luar kawasan lindung, yang berfungsi sebagai lingkungan tempat tinggal dan tempat kegiatan yang mendukung perikehidupan dan penghidupan yang sehat dan aman yang didukung dengan prasarana, sarana dan utilitas umum (PSU) dengan penataan sesuai dengan standar dan tata ruang yang berlaku serta menjamin kesehatan masyarakat. Hal ini didukung oleh pendapat Kurniasih (2007), pemukiman dapat terhindar dari kondisi kumuh dan tidak layak huni jika pembangunan perumahan dan permukiman sesuai dengan standar yang berlaku,sehingga dapat disimpulkan bahwa permukiman dikatakan layak apabila kondisi elemen fisik permukimannya memenuhi standar yang berlaku. Secara khusus tujuan penelitian ini ingin menjawab tetang ketercapaian perwujudan permukiman layak huni dalam rangka program PLPBK ini, dinilai tidak hanya berdasarkan tingkat kesesuian kondisi fisik lingkungan permukiman dengan kriteria permukiman layak huni namun juga bagaimana peningkatan kondisi fisik lingkungan permukiman sebelum dan sesudah pelaksanaan program PLPBK di lokasi penelitian.

\section{METODE}

Penelitian ini bermaksud untuk mendapatkan gambaran mengenai kondisi fisik lingkungan permukiman dari hasil pembangunan program penataan lingkungan permukiman berbasis komunitas (PLPBK), untuk mengetahui sejauh mana ketercapaian perwujudan lingkungan permukiman layak huni di Kabupaten Karanganyar dari sudut pandang normatif yaitu dengan menggunakan standar pelayanan minimum (SPM) sebagai dasar pengukuran ketercapaian.

Pendekatan pemikiran dalam penelitian ini bersifat deduktif karena penelitian diuji dengan teori-teori yang ada untuk mendapatkan jawaban dari tujuan penelitian yang diangkat.Penelitian ini juga merupakan penelitian terapan, yaitu penelitian terhadap suatu masalah dengan tujuan untuk digunakan bagi keperluan tertentu (Nazir, 1988).Penelitian yang dilakukan ini menggunakan pendekatan deskriptif rasionalistik yang didasari penggunaan logika sebagai dasar penelitian dalam menanggapi fenomena yang muncul. Pendekatan deskriptif rasionalistik 
berorientasi pada upaya memahami fenomena secara menyeluruh yang mengarah pada pencarian kesimpulan dengan mengungkap makna dan intepretasi masalah terhadap pemahaman obyek yang diteliti (Danim dalam Kusumaningsih,2005)

Penelitian ini dilakukan pada desa lokasi lama yaitu lokasi tahun pelaksanaan 2010 antara lain Desa Lalung, Desa Karangmojo, Desa Gedong, Desa Suruh dan Desa Kalijirak

\section{HASIL DAN PEMBAHASAN}

\subsection{Kondisi Sarana Niaga}

Sarana niaga di lokasi penelitian terjadi peningkatan yang tinggi yaitu penambahan ruko dan kios setelah pelaksanaan program di lokasi penelitian. Sedangkan tingkat ksesuaian kondisi sarana niaga di lokasi penelitian terhadap kriteria permukiman layak huni dinilai kurang sesuai karena sarana niaga berupa pasar tradisonal di lokasi penelitian tidak menjangkau wilayah di lokasi penelitian, namun kawasan permukiman di lokasi penelitian terjangkau oleh pasar tradisional dari luar wilayah lokasi penelitian

\subsection{Kondisi Sarana Pendidikan}

Sarana pendidikan berupa TK, SD dan SMP setelah pelaksanaan program mengalami penambahan 4 unit sarana TK. Sebelum pelaksanaan program terdapat 10 unit TK, 7 unit SD dan 6 unit SMP, setelah pelaksanaan program menjadi 14 unit TK, 7 unit SD dan 6 unit SMP. Dapat diketahui bahwa peningkatan sarana pendidikan berupa TK dinilai tinnggi yaitu terjadi penambahan 4 unit sarana TK, sedangkan untuk sarana SD dan SMP dinilai rendah karena tidak terjadi peningkatan/ perubahan. Sedangkan untuk kesesuaiannya berdasar radius jangkauan pelayanan sarana pendidikan diketahui bahwa untuk sarana TK, SD dan SMP dunilai sesuai karena mampu menjangkau sebagian besar kawasan di lokasi penelitian.

\subsection{Kondisi Sarana Kesehatan}

Sarana kesehatan berupa PKD dan Puskesmas setelah pelaksanaan program hanya mengalami peningkatan kualitas PKD pada beberapa desa. Sebelum dan setelah pelaksanaan program terdapat 5 unit PKD namun tidak terdapat puskesmas, sehingga dapat diketahui bahwa hanya terjadi peningkatan kualitas sarana PKD dan peningkatannya dinilai sedang, sedangkan untuk sarana Puskesmas dinilai rendah karena tidak terjadi peningkatan/ perubahan.

Sedangkan untuk kesesuaiannya berdasar radius jangkauan pelayanan sarana kesehatan diketahui bahwa untuk sarana PKD dan Puskesmas dinilai kurang sesuai karena hanya beberapa wilayah permukiman yang terlayani dengan sarana Kesehatan PKD namun wilayah dilokasi penelitian juga terjangkau dengan sarana kesehatan puskesmas dari luar lokasi penelitian

\subsection{Kondisi Sarana Pelayanan Umum}

Sarana pelayanan umum berupa gedung pertemuan setelah pelaksanaan program mengalami peningkatan yaitu penambahan jumlah sarana pelayanan umum sebanyak 2 unit gedung serbaguna, sehingga dapat diketahui bahwa peningkatan sarana pelayanan umum dinilai tinggi karena terjadi penambhan 2 unit gedung serba guna di lokasi penelitian.

Sedangkan untuk kesesuaiannya berdasar jangkauan pelayanan penduduk sarana pelayanan umum diketahui bahwa untuk sarana pelayanan umum dinilai kurang sesuai karena hanya tersedia 9 unit gedung pertemuan dimana seharusnya 
terdapat 12 unit gedung pertemian untuk memenuhi kebutuhan masyarakat di lokasi penelitian.

\subsection{Kondisi Sarana Ruang Terbuka}

Sarana ruang terbuka setelah pelaksanaan program mengalami peningkatan yaitu penambahan jumlah sarana ruang terbuka sebanyak 2 lokasi taman lingkungan dan hampir setiap bagian desa di lokasi penelitian terjangkau dengan area hijau. Dapat diketahui bahwa peningkatan sarana ruang terbuka dinilai tinggi karena terjadi penambahan 2 lokasi taman lingkungan dan hampir setiap bagian desa di lokasi penelitian terjangkau dengan area hijau.

Sedangkan untuk kesesuaiannya berdasar jangkauan pelayanan penduduk sarana sarana ruang terbuka, diketahui bahwa untuk sarana ruang terbuka dinilai sesuai karena mampu melayani sebagian besar wilayah permukiman dilokasi penelitian dengan sarana RTH berupa lapangan, taman dan lahan hijau.

\subsection{Kondisi Jaringan Jalan}

Peningkatan kondisi jaringan jalan dilokasi penelitian di nilai tinggi karena terjadi peningkatan kondisi jaringan jalan dimana sebagian besar kondisi jalan di dominasi oleh jaringan jalan yang sedang baik.

Sedangkan untuk kesesuan jaringan jalan di lokasipenelitian di nilai sesuai karena Permukiman di lokasi penelitian terjangkau dengan jaringan jalan lingkungan dengan kondisi yang baik dan lebar jalan 3-5m

\subsection{Kondisi Jaringan Drainase}

Peningkatan kondisi jaringan drainase di lokasi penelitian dinilai tinggi karena terjadi peningkatan kondisi jaringan drainase dimana sebagian besar titik lokasi genangan mampu teratasi.Sedangkan untuk kesesuan jaringan drainase di lokasi penelitian dinilai sesuai karena Kondisi jaringan drainase di lokasi penelitian jarang sekali terjadi genangnan banjir bahkan saat musim hujan

\subsection{Kondisi Jaringan Air Limbah}

Peningkatan kondisi jaringan air limbah dilokasi penelitian di nilai sedang karena terjadi peningkatan kepemilikan jaringan air limbah dimana peningkatan kepemilikan jaringan air limbah di lokasi penelitian mengalami peningkatan sebesar $27,4 \%$.

Sedangkan kesesuaian jaringan air limbah di lokasi penelitian di nilai sesuai karena Jumlah penduduk yang terjangkau dengan jaringan air limbah $>80 \%$ yaitu sebesar $98.7 \%$.

\subsection{Kondisi Jaringan Persampahan}

Peningkatan kondisi jaringan persampahan di lokasi penelitian dinilai sedang karena terjadi peningkatan dalam pemanfaatan Sistem DK/PDK \& Saniter individual composting sebesar 28,07\%.Sedangkan kesesuaian jaringan persampahan di lokasi penelitian dinilai kurang sesuai karena jumlah penduduk yang terjangkau dengan pengelolaan sampah dengan sistem DK/PDK \& saniter individual composting antara 33,4-66,6\%.

\subsection{Kondisi Jaringan Air Bersih}

Peningkatan kondisi jaringan air bersih di lokasi penelitian dinilai sedang karenaKeterjangkauan masyarakat akan jaringan air bersih terjadi peningkatan sebanyak $19 \%$.

Sedangkan kesesuaian jaringan persampahan di lokasi penelitian di nilai sesuai karena jumlah penduduk yang terjangkau dengan jaringan air bersih $>75$ $\%$ yaitu $98 \%$.

\subsection{Analisis Peningkatan Kondisi Fisik Lingkungan Permukiman}


Peningkatan kondisi elemen fisik lingkungan permukiman bervariasi beberapa mengalami peningkatan yang rendah seperti sarana pendidikan berupa SD dan SMP, sarana kesehatan berupa puskesmas, jaringan air limbah, jaringan persampahan dan jaringan air bersih. Untuk peningkatan sedang antara lain kesehatan berupa PKD, sedangkan yang mengalami peningkatan tinggi antara lain sarana niaga, sarana pendidikan berupa TK, sarana pelayanan umum, sarana ruang terbuka, jaringan jalan dan jaringan drainase. Berdasarkan hasil skoring peningkatan kondisi fisik lingkungan permukiman di kabupaten Karanganyar secara menyeluruh didapatkan nilai sebesar 74.3\% yang berarti peningkatan kondisi fisik lingkungan permukiman di Kabupaten Karanganyar adalah tinggi (Lampiran 1)

\subsection{Analisis Tingkat Kesesuaianan Kondisi}

Fisik Lingkungan Permukiman dengan Kriteria Permukiman Layak Huni

Kesesuaian kondisi elemen fisik lingkungan permukiman bervariasi, beberapa elemen dinilai kurang sesuai seperti sarana niaga, sarana kesehatan berupa PKD dan puskesmas serta sarana pelayanan umum. Sedangkan elemen yang dinilai sesuai antara lain sarana ruang terbuka, jaringan jalan, jaringan drainase, jaringan air limbah, jaringan persampahan dan jaringan air bersih . Berdasarkan hasil skoring tingkat kesesuaian kondisi elemen fisik lingkungan permukiman dengan kriteria permukiman layak huni di kabupaten karanganyar secara menyeluruh didapatkan nilai sebesar $87.2 \%$ yang berarti kesesuaian kondisi elemen fisik lingkungan permukiman dengan kriteria permukiman layak huni di kabupaten karanganyar adalah tinggi (Lampiran 2)

\subsection{Analisis Ketercapaian Perwujudan Lingkungan Permukiman Layak Huni}

Berdasarkan hasil pengolahan data, maka dapat disimpulkan beberapa hasil pendataan bahwa variabel peningkatan kondisi fisik lingkungan permukiman di Kabupaten Karanganyar secara menyeluruh didapatkan nilai sebesar $66.7 \%$ yang berarti peningkatan kondisi fisik lingkungan permukiman di Kabupaten Karanganyar adalah tinggi, sedangkan tingkat kesesuaian kondisi elemen fisik lingkungan permukiman dengan kriteria permukiman layak huni di kabupaten karanganyar secara menyeluruh didapatkan nilai sebesar $87.2 \%$ yang berarti kesesuaian kondisi elemen fisik lingkungan permukiman dengan kriteria permukiman layak huni di kabupaten karanganyar adalah tinggi. Dengan diketahuinya peningkatan dan tingkat kesesuaian kondisi elemen fisik lingkungan permukiman maka dapat diketahui ketercapaian perwujudan lingkungan permukiman layak huni di Kabupaten Karanganyar dengan melakukan skoring dengan hasil analisis peningkatan dan tingkat kesesuaian kondisi elemen fisik lingkungan permukiman yang didapatkan hasil nilai sebesar $76.9 \%$ yang berarti ketercapaian perwujudan lingkungan permukiman layak huni dalam rangka program PLPBK di Kabupaten Karanganyar adalah tercapai (Lampiran 3)

\section{KESIMPULAN}

Dilihat dari setiap sasaran yang akan dicapai pada awal penelitian, di mana sasaran pertama diketahui peningkatan kondisi fisik lingkungan permukiman dengan melihat perubahan kondisi masing masing elemen fisik lingkungan permukiman sebelum dan sesudah pelaksanaan program PLPBK di Kabupaten Karanganyar dinilai tinggi. 
Kemudian dari sasaran kedua yaitu diketahuitingkat kesesuaian kondisi fisik lingkungan permukiman dengan membandingkan kondisi masing - masing elemen fisik lingkungan permukiman sesudah pelaksanaan program PLPBK di Kabupaten Karanganyar dengan kriteria permukiman layak huni dinilai tinggi. sehingga dapat diketahui dengan peningkatan kondisi fisik lingkungan permukiman mendapatkan persentase sebesar 66,7 \% dan termasuk dalam kategori peningkatan tinggi sedangkan tingkat kesesuaian kondisi fisik lingkungan permukiman dengan kriteria permukiman layak huni mendapatakan persentase sebesar 87,2 \% dan termasuk dalam kategori tinggi. Sehingga berdasarkan analisis skoring antar hasil analisis peningkatan dan tingkat kesesuaian koondisi fisik lingkungan permukiman terhadap permukiman layak huni maka pencapaian lingkuangan permukiman layak huni mendapatkan persentase sebesar $76.9 \%$ yang berarti bahwa ketercapaian perwujudan lingkungan permukiman layak huni dalam rangka program PLPBK di Kabupaten Karanagnyar dinilai tercapai.

Ketercapaian perwujudan lingkungan permukiman layak huni dalam rangka program penataan lingkungan permukiman berbasis komunitas (PLPBK) di Kabupaten Karanganyar dinilai tercapai selain dinilai dari hasil peningkatan dan tingkat kesesuaian kondisi fisik lingkungan permukiman, berdasarkan hasil penemuan dilapangan ketepatan sasaran pembangunan juga memberikan pengaruh terhadap hasil pembangunan dimana dalam hal ini adalah ketercapaian perwujudan lingkungan permukiman layak huni di Kabupaten Karanganyar

\section{REFERENSI \\ BUKU}

Arikunto, Suharsimi, 2006. Prosedur Penelitian

Suatu Pendekatan Praktik, Rineka Cipta, Jakarta.

Budihardjo, Eko, 1984. Sejumlah Masalah Permukiman Kota, Bandung : Penerbit Alumni Bappenas. 2003. Buku Pelatihan Substantif Perencanaan Spasial tentang Dasar-dasar Perencanaan Perumahan dan permukiman. Pusbindiklatren Bappenas

Harinaldi. M.Eng, (2005). Pronsip - Prinsip Statistik Untuk Teknik Dan Sains, Penerbit : Erlangga, Jakarta.

Hariyono, Paulus, (2007), Sosiologi Kota untuk Arsitek, Jakarta : PT. Bumi Aksara

Kartasasmita, Ginandjar. 1996. Pemberdayaan Masyarakat: Sebuah Tinjauan Administrasi. Malang: Universitas Brawijaya

Khomarudin, 1992. Menelusuri Pembangunan Perumahan Dan Permukiman. Yayasan Realestate Indonesia

Kurniasih, Sri. 2007. Usaha Perbaikan Permukian Kumuh Di Petukangan Utara Jakarta Selatan.Tesis.Teknik Arsitektur Universitas Budi Luhur

Masyhuri, M. Zainuddin. 2008. Metodologi Penelitian Pendekatan Praktis dan Aplikatif. Bandung: PT. Refika Aditama

Muta'ali, Lutfi. 2013. Penataan Ruang Wilayah dan Kota (Tinjauan Normatif Teknis).Yogyakarta : Badan Penerbit Fakultas Geografi.

Nazir M. 2005. Metode Penelitian.Ghalia Indonesia: Bogor.

Nasution, Lutfi I. (ed). 1996. Memahami dan Menanggulangi Kemiskinan di Indonesia- 70 
Tahun Prof. Sajogyo. Jakarta: PT Gramedia Widiasarana

Riduwan, 2009, Metode \& Teknik Menyusun Tesis, Bandung: Penerbit Alfabeta

Sastra M., Suparno, dan Endy Marlina. 2006.

Perencanaan dan Pengembangan Perumahan.

Yogyakarta :Penerbit Andi

Silas, Johan. 1996. Kampung surabaya menuju mtropolitan, permukiman marjinal amat liar. Siregar, Syofian. 2013. Metode Penelitian Kuantitatif. Jakarta :Kencana Prenada Media Group

Sugiyono, 2010, Metode Penelitian Kuantitatif, Kualitatif dan RND, Bandung: PenerbitAlfabeta UNESCAP dan UN-HABITAT. 2009. Panduan ringkasuntuk pembuat kebijakan. UNESCA PERATURAN

Direktorat Jenderal Cipta Karya Departemen

Pekerjaan Umum dan Deputi Bidang

Pengkajian Kebijaksanaan Teknologi Badan

Pengkajian Dan Penerapan Teknologi.1992.

Pembangunan
Perkotaanberwawasanlingkungan. Jakarta.

Penerbit Departemen Pekerjaan Umum

Direktorat Jendral Cipta Karya dalam pedoman perencanaan permukiman tentang permukiman layak

Menteri Pekerjaan Umum Nomor : 378/KPTS/1987 tentang Pengesahan 33 Standar Konstruksi Bangunan Indonesia

Permenpera No.22 Th 2008 Standar Pelayanan Minimal Bidang Perumahan Rakyat Daerah Provinsi Dan Daerah Kabupaten/Kota Undang -undang No.1 tahun 2011 Pedoman Teknis Prasarana Jalan Perumahan, 1998

Keputusan Menteri Permukiman dan Prasarana Wilayah No. 534/KPTS/M/2001

SNI 03-1733-2004 tata cara perencanaan lingkungan perumahan di perkotaan

SK-SNI-T-12-1991-03 Tentang Tata Cara Pengelolaan Sampah Permukiman 


\section{LAMPIRAN}

\section{Lampiran 1}

Tabel Peningkatan kondisi fisik lingkungan permukiaman di Kabupaten Karanganyar

\begin{tabular}{|c|c|c|c|}
\hline \multicolumn{2}{|c|}{$\begin{array}{l}\text { Elemen Fisik Lingkunagn } \\
\text { Permukiman }\end{array}$} & \multicolumn{2}{|c|}{$\begin{array}{c}\text { Peningkatan Kondisi } \\
\text { Fisik Lingkungan } \\
\text { Permukiman }\end{array}$} \\
\hline $\begin{array}{l}\text { Sarana } \\
\text { Niaga }\end{array}$ & $\begin{array}{l}\text { Pasar } \\
\text { Tradisional }\end{array}$ & Tinggi & 3 \\
\hline \multirow[t]{3}{*}{$\begin{array}{l}\text { Sarana } \\
\text { Pendidikan }\end{array}$} & TK & Tinggi & 3 \\
\hline & SD & Rendah & 1 \\
\hline & SMP & Rendah & 1 \\
\hline \multirow[t]{2}{*}{$\begin{array}{l}\text { Sarana } \\
\text { Kesehatan }\end{array}$} & PKD & Sedang & 2 \\
\hline & Puskesmas & Rendah & 1 \\
\hline $\begin{array}{l}\text { Sarana } \\
\text { Pelayanan } \\
\text { Umum }\end{array}$ & $\begin{array}{l}\text { Gedung } \\
\text { Serbaguna }\end{array}$ & Tinggi & 3 \\
\hline $\begin{array}{l}\text { Sarana } \\
\text { Ruang } \\
\text { Terbuka }\end{array}$ & RTH & Tinggi & 3 \\
\hline \multicolumn{2}{|c|}{ Jaringan Jalan Lingkungan } & Tinggi & 3 \\
\hline \multicolumn{2}{|c|}{ Jaringan Drainase } & Tinggi & 3 \\
\hline \multicolumn{2}{|c|}{ Jaringan Air Limbah } & Sedang & 2 \\
\hline \multicolumn{2}{|c|}{ Jaringan Persampahan } & Sedang & 2 \\
\hline \multicolumn{2}{|c|}{ Jaringan Air Bersih } & Sedang & 2 \\
\hline \multicolumn{2}{|l|}{ Jumlah } & \multicolumn{2}{|l|}{29} \\
\hline \multicolumn{2}{|c|}{ Persentase peningkatan $(\%)$} & \multicolumn{2}{|l|}{74.3} \\
\hline \multicolumn{2}{|c|}{ Kategori } & \multicolumn{2}{|l|}{ Tinggi } \\
\hline
\end{tabular}

Sumber : Analisis Penulis, 2015 


\section{Lampiran 2}

Tabel Kesesuaian Kondisi Fisik Lingkungan Permukiaman Dengan Kriteria Permukiman Layak Huni Di Kabupaten Karanganyar

\begin{tabular}{|c|c|c|c|}
\hline \multicolumn{2}{|c|}{$\begin{array}{l}\text { Elemen Fisik Lingkunagn } \\
\text { Permukiman }\end{array}$} & \multicolumn{2}{|c|}{$\begin{array}{l}\text { Kesesuaian Kondisi } \\
\text { Fisik Lingkungan } \\
\text { Permukiman }\end{array}$} \\
\hline $\begin{array}{l}\text { Sarana } \\
\text { Niaga }\end{array}$ & $\begin{array}{l}\text { Pasar } \\
\text { Tradisional }\end{array}$ & $\begin{array}{l}\text { Kurang } \\
\text { sesuai }\end{array}$ & 2 \\
\hline \multirow[t]{3}{*}{$\begin{array}{l}\text { Sarana } \\
\text { Pendidikan }\end{array}$} & TK & Sesuai & 3 \\
\hline & SD & Sesuai & 3 \\
\hline & SMP & Sesuai & 3 \\
\hline \multirow[t]{2}{*}{$\begin{array}{l}\text { Sarana } \\
\text { Kesehatan }\end{array}$} & PKD & $\begin{array}{c}\text { Kurang } \\
\text { sesuai }\end{array}$ & 2 \\
\hline & Puskesmas & $\begin{array}{l}\text { Kurang } \\
\text { sesuai }\end{array}$ & 2 \\
\hline $\begin{array}{l}\text { Sarana } \\
\text { Pelayanan } \\
\text { Umum } \\
\end{array}$ & $\begin{array}{l}\text { Gedung } \\
\text { Serbaguna }\end{array}$ & $\begin{array}{l}\text { Kurang } \\
\text { sesuai }\end{array}$ & 2 \\
\hline $\begin{array}{l}\text { Sarana } \\
\text { Ruang } \\
\text { Terbuka }\end{array}$ & RTH & Sesuai & 3 \\
\hline \multicolumn{2}{|c|}{ Jaringan Jalan Lingkungan } & Sesuai & 3 \\
\hline \multicolumn{2}{|c|}{ Jaringan Drainase } & Sesuai & 3 \\
\hline \multicolumn{2}{|c|}{ Jaringan Air Limbah } & Sesuai & 2 \\
\hline \multicolumn{2}{|c|}{ Jaringan Persampahan } & $\begin{array}{c}\text { Kurang } \\
\text { sesuai }\end{array}$ & 3 \\
\hline \multicolumn{2}{|c|}{ Jaringan Air Bersih } & Sesuai & 3 \\
\hline \multicolumn{2}{|l|}{ Jumlah } & \multicolumn{2}{|l|}{34} \\
\hline \multicolumn{2}{|l|}{$\begin{array}{l}\text { Persentase } \\
(\%)\end{array}$} & \multicolumn{2}{|l|}{87.2} \\
\hline \multicolumn{2}{|l|}{ Kategori } & \multicolumn{2}{|l|}{ Tinggi } \\
\hline
\end{tabular}


Lampiran 3

Tabel Ketercapaian Perwujudan Lingkungan Permukiman Layak Huni

\begin{tabular}{|c|c|c|c|c|c|}
\hline \multicolumn{2}{|c|}{ Elemen Fisik Lingkunagn Permukiman } & \multicolumn{2}{|c|}{$\begin{array}{l}\text { Peningkatan Kondisi Fisik } \\
\text { Lingkungan Permukiman }\end{array}$} & \multicolumn{2}{|c|}{$\begin{array}{l}\text { Tingkat Kesesuaian Kondisi } \\
\text { Fisik Lingkungan Permukiman }\end{array}$} \\
\hline Sarana Niaga & Pasar Tradisional & Tinggi & 3 & Kurang sesuai & 2 \\
\hline \multirow[t]{3}{*}{ Sarana Pendidikan } & TK & Tinggi & 3 & Sesuai & 3 \\
\hline & SD & Rendah & 1 & Sesuai & 3 \\
\hline & SMP & Rendah & 1 & Sesuai & 3 \\
\hline \multirow[t]{2}{*}{ Sarana Kesehatan } & PKD & Sedang & 2 & Kurang sesuai & 2 \\
\hline & Puskesmas & Rendah & 1 & Kurang sesuai & 2 \\
\hline $\begin{array}{l}\text { Sarana Pelayanan } \\
\text { Umum }\end{array}$ & \begin{tabular}{|l} 
Gedung \\
Serbaguna
\end{tabular} & Tinggi & 3 & Kurang sesuai & 2 \\
\hline $\begin{array}{l}\text { Sarana Ruang } \\
\text { Terbuka }\end{array}$ & RTH & Tinggi & 3 & Sesuai & 3 \\
\hline \multicolumn{2}{|c|}{ Jaringan Jalan Lingkungan } & Tinggi & 3 & Sesuai & 3 \\
\hline \multicolumn{2}{|c|}{ Jaringan Drainase } & Tinggi & 3 & Sesuai & 3 \\
\hline \multicolumn{2}{|l|}{ Jaringan Air Limbah } & Sedang & 2 & Sesuai & 3 \\
\hline \multicolumn{2}{|c|}{ Jaringan Persampahan } & Sedang & 2 & Kurang sesuai & 2 \\
\hline \multicolumn{2}{|c|}{ Jaringan Air Bersih } & Sedang & 2 & Sesuai & 3 \\
\hline \multirow{2}{*}{\multicolumn{2}{|c|}{ Jumlah }} & \multicolumn{2}{|c|}{29} & \multicolumn{2}{|c|}{34} \\
\hline & & \multicolumn{4}{|c|}{60} \\
\hline \multicolumn{2}{|c|}{ Persentase peningkatan $(\%)$} & \multicolumn{4}{|c|}{80.76} \\
\hline \multicolumn{2}{|l|}{ Kategori } & \multicolumn{4}{|c|}{ Tercapai } \\
\hline
\end{tabular}

Sumber : Analisis Penulis, 2015 
